\title{
Morphological, cytological and molecular variations induced by gamma rays in Chrysanthemum morifolium 'Donglinruixue'
}

\author{
Ling Wang*, Jianhui Wu, Feng Lan, Pengfei Gao
}

Northeast Forestry University, Harbin, China

\begin{abstract}
The current study investigated the effects of gamma radiation on the death rate, morphological traits and meiotic abnormalities in ground-grown chrysanthemum 'Donglinruixue', and inter-simple sequence repeat (ISSR) markers were used to identify the DNA polymorphism among mutants. The results showed that the death rate significantly increased with increase in radiation dose. Semi-lethal (LD50) dose was approximately $35 \mathrm{~Gy}$. Compared with unirradiated control, plant growth was significantly inhibited. After irradiation, a series of morphological variations and cytological aberrations occurred in radiated plants. The peak in variation frequency appeared at $35 \mathrm{~Gy}$. In total, ISSR analysis produced 72 scorable bands, of which $64(88.89 \%)$ were polymorphic. The current study demonstrated that gamma irradiation generates a sufficient number of induced mutations and that ISSR analysis offered a useful molecular marker analysis for the identification of mutants.
\end{abstract}

Keywords: death rate, DNA, gamma irradiation, ground-grown chrysanthemum, ISSR, meiosis

\section{INTRODUCTION}

Ground-grown chrysanthemum is a new cultivar group, of which Professor Xiao-fang Zhang introduced the ground-cover chrysanthemum and Beijing chrysanthemum, which was then selectively bred using natural hybridisation and space breeding by satellitecarrying. Ground-grown chrysanthemum is widely used in Northern China in autumn greening due to flower characteristics, such as density, long flowering period, dwarf plants, easy cultivation and resistance to extensive management (Chen et al., 1995). Groundgrown chrysanthemum 'Donglinruixue' is a cultivar of Beijing chrysanthemum 'Xuetuan' group bred by natural pollination. In recent years, 'Donglinruixue' was observed with cultivar in degeneration with plants becoming taller and branching more. Therefore, it is imperative to improve and cultivate the cultivar 'Donglinruixue' with dwarfing characteristics.
Breeding novel cultivars using conventional crossbreeding constantly present a challenge because many horticultural species are genetically and highly heterozygous, and hybrid lines are difficult to segregate from their parents. However, the advantage of mutation breeding is genetic modification of one or more traits without changing resources (Wani and Anis, 2008). Gamma irradiation is a suitable method of mutation breeding for creation of the desired traits in cultivated plants. It is also one of the most and highly energetic forms of electromagnetic radiations and is more penetrating than other types of radiations (Kovacs and Keresztes, 2002; Hwang et al., 2016). Thus, using this radiation presents a promising breeding technique compared with traditional breeding (Majeed et al., 2009). Many breeding methods, including basic genetic research and improvement programmes, have 
been broadly applied (Ahloowalia and Maluszynski, 2001; Mahto and Das, 2014) in major crops including ornamental plants (Banelji and Datta, 2006; Kang et al., 2013).

Gamma irradiation has been considered to be very useful for cultivating new varieties of chrysanthemum (Matsumura et al., 2010; Sung et al., 2013). The research level is confined to morphological and histological anatomy (Lamseejan et al., 2000; Yamaguchi et al., 2008); however, morphological and cytological traits cannot reflect their genotypic characteristics and hence inter-simple sequence repeat (ISSR) markers are also selected for molecular analysis. Molecular technology has been broadly applied to investigate genetic polymorphism because it provides more accurate results compared with other methods (Rustikawati et al., 2012). As a molecular technique, ISSR analysis can screen 100-3,000 bp DNA fragments (Zietkiewicz et al., 1994; Taheri et al., 2013). ISSR has been broadly used to estimate genetic diversity, genetic stability, genetic characterisation and identification and screening of mutant plants (Mariano et al., 2019; Mejri et al., 2012). The main advantage of ISSR is that it is randomly distributed throughout the genome, and the results are reproducible (Mudibu et al., 2002; Afrasiab and Iqbal, 2011). The objective of this research was to develop a suitable technique for mutation breeding and, at the cellular and molecular level, to explore the mutagenic effects and mutagenesis mechanisms of gamma rays on ground-grown chrysanthemum. For this purpose, we investigated the effect of different doses of gamma irradiation on the death rate, morphological traits and meiotic abnormalities of 'Donglinruixue' and identified DNA polymorphism among the mutants through ISSR marker analysis.

\section{MATERIALS AND METHODS}

\section{Plant materials}

A chrysanthemum cultivar, Chrysanthemum morifolium 'Donglinruixue' (supplied by Northeast Forestry University Nursery Test Base, Harbin, China), was used as experimental material. After 20 days of culture of singular mother plants propagated from cuttings, healthy rooted winter suckers of $2 \pm 0.5 \mathrm{~cm}$ long were used for radiation treatment.

\section{Gamma-ray treatment}

Rooted cuttings of 'Donglinruixue' were exposed to ${ }^{60} \mathrm{Co}-\gamma$ (gamma-ray) radiation source at the dose rate of $0.9 \mathrm{~Gy} \cdot \mathrm{min}^{-1}$. Six separate radiation doses were used: $0,15,20,25,30$ and 35 Gy. Thirty rooted cuttings per treatment were irradiated to appropriate doses, and untreated rooted cuttings served as control. Each treatment was replicated thrice. The total amount of samples is 540 . The radiation source was supplied by the Heilongjiang Academy of Agricultural Sciences (Harbin, China). After radiation, rooted cuttings of irradiated and unirradiated 'Donglinruixue' were planted in plastic pots $(10 \times 10 \times 10 \mathrm{~cm})$ containing an autoclaved mixture of soil, vermiculite and medium sand (4:1:1) in the greenhouse. The amount of mixture in each plastic pot was the same, and one rooted cutting was planted per plastic pot. Each treatment included 30 pots. Temperature and relative humidity were kept at $20 \pm 2{ }^{\circ} \mathrm{C}$ and $70 \%$, respectively. Cultures were irrigated twice a week.

\section{Measurement of death rate and morphological variations}

The death rate of irradiated cuttings was measured. After radiation, data of measurements were recorded every 7 days for 28 days. After 120 days of plant culture after treatment, the plants were measured from stem base to shoot tip. Each treatment was repeated thrice. Two weeks after culture initiation, the frequency of morphological variation at different radiation doses was measured as the index reflecting the effect of radiation on plant morphological changes. According to the formula (Walther, 1969), variation frequency $(\%)=($ No. of variations/No. of treated plants) $\times 100 \%$, frequency of morphological variation was calculated.

\section{Meiotic analysis}

For meiotic studies, young floral buds both control and irradiated ones were collected in the sunny morning from 8 a.m. to 10 a.m., and they were fixed in Carnoy's fixative II (three parts absolute ethanol and one part glacial acetic acid) for $24 \mathrm{~h}$, subsequently washed and preserved in $70 \%$ alcohol at $4{ }^{\circ} \mathrm{C}$. Anthers were stained in improved phenolic phenol dye and destained to the desired extent with $45 \%$ acetic acid. The chromosome behaviour at different meiotic stages in pollen mother cells was observed. The meiotic phases of each treatment were evaluated in more than 1,000 microsporocytes. Each treatment group was repeated three times. Cells with aberrations were recorded and used for the calculation of abnormality percentage. Under the Leica DM2500 microscope, chromosomes of the meiosis at different phases were observed and taken pictures.

\section{DNA extraction and ISSR polymerase chain reaction (PCR) amplification}

Leaf samples were collected from phenotypic variants of different radiation treatments (Table 1). Total genomic DNA was isolated from fresh leaf tissues using a DNA isolation kit (TIANGEN, Beijing, China). Isolated DNA was quantified on a spectrophotometer (Biomate 3). A total of 13 primers were selected from 36 ISSR primers, and they were used to provide PCR products for the assessment of genetic stability of plants. The amplification reaction was carried out in $25 \mu \mathrm{L}$ reaction volume containing $2.5 \mu \mathrm{L} 10 \times$ PCR buffer, $2.5 \mu \mathrm{L} 25 \mathrm{mM}$ deoxynucleotide triphosphates, $2.5 \mu \mathrm{L}$ $25 \mathrm{mM} \mathrm{MgSO}$, $1 \mu \mathrm{L}$ primer (Xinhai Gene Biological Engineering Technology and Service Co. Ltd., 
Harbin, China), 0.5 U Taq DNA polymerase (Toyobo Ideas and Chemistry Co., Ltd., Tokyo, Japan) and 50 ng of template DNA. Reaction mixtures were exposed to the following conditions: $94^{\circ} \mathrm{C}$ for $2 \mathrm{~min}$, followed by 44 cycles of $10 \mathrm{~s}$ at $98^{\circ} \mathrm{C}, 30 \mathrm{~s}$ at annealing temperature, $30 \mathrm{~s}$ extension at $68^{\circ} \mathrm{C}$ and a final $7 \mathrm{~min}$ extension at $68^{\circ} \mathrm{C}$. Amplification products, along with a GeneRuler 5,000 ladder (Takara BIO, Inc.), were separated via electrophoresis on $2 \%(\mathrm{w}: \mathrm{v})$ agarose gels with $1 \times$ Tris-acetate-ethylenediaminetetraacetic acid buffer at $120 \mathrm{~V}$ for $15 \mathrm{~min}$ and stained with ethidium bromide $\left(0.1 \mathrm{mg} \cdot \mu \mathrm{L}^{-1}\right)$. The samples were then photographed using an Image Quant LAS 4000.

\section{Statistical analysis}

Statistical Product and Service Solutions (SPSS) 20.0 was used for statistical analysis. Data of all parameters were analysed using analysis of variance

Table 1. List of mutants in chrysanthemum 'Donglinruixue' used for diversity analysis

\begin{tabular}{ll}
\hline $\begin{array}{l}\text { Irradiation } \\
\text { dose (Gy) }\end{array}$ & Type of mutation \\
\hline $0 \mathrm{~Gy}$ & No variations \\
$15 \mathrm{~Gy}$ & Increased leaf crack \\
$20 \mathrm{~Gy}-1$ & Reduced number of petals \\
$20 \mathrm{~Gy}-2$ & $\begin{array}{l}\text { Leaves missing green colour, increased leaf } \\
\text { crack }\end{array}$ \\
$25 \mathrm{~Gy}-1$ & Rolled leaves \\
$25 \mathrm{~Gy}-2$ & Lanceolate leaves, increased tubular flowers \\
$25 \mathrm{~Gy}-3$ & Lanceolate leaves, decreased number of petals \\
$30 \mathrm{~Gy}$ & $\begin{array}{l}\text { Increased leaf cracks and reduced number of } \\
\text { petals }\end{array}$ \\
$35 \mathrm{~Gy}-1$ & Rolled leaves \\
$35 \mathrm{~Gy}-2$ & Plant dwarfing, twisted ligulate flowers \\
\hline
\end{tabular}

and Duncan's multiple range test. The results with $p<0.05$ were considered statistically significant. Excel 2007 was used for graphical illustration. Values were expressed by means \pm standard error (SE). Data of ISSR marker analysis were scored into a matrix with values of ' 1 ' for the presence and ' 0 ' for the absence of bands for each primer pair. This $0-1$ matrix was subjected to genetic similarity analysis using Jaccard's coefficient. Clustering was performed using sequential agglomerative hierarchical non-overlapping (SAHN), and dendrogram was constructed by unweighted paired group method using arithmetic averages (UPGMA) with the aid of Numerical Taxonomy and Multivariate Analysis System (NTSYS-PC).

\section{RESULTS}

\section{Effect of radiation on the death rate of 'Donglinruixue'}

Figure 1 shows the death rates observed in control and treated plants of 'Donglinruixue'. Higher radiation dose resulted in earlier plant death. At the same dose, the death rate of 'Donglinruixue' increased with treatment time (Figure 1). Low doses of radiation had little effect on plant damage, and only 2 weeks later radiation showed damage to plants. Three weeks after radiation, the death rate of 30 Gy treatment significantly increased. Four weeks after radiation, the semi-lethal state was enhanced at $35 \mathrm{~Gy}$.

\section{Effect of radiation on the plant morphological variations of 'Donglinruixue'}

After 120 days of culture after treatment, the effect of radiation on the growth of plants was also notable. Plant height followed a downward trend, and it was significantly decreased at high doses (30 and 35 Gy) which were 28.14 and $68.87 \%$ of that of controls, respectively

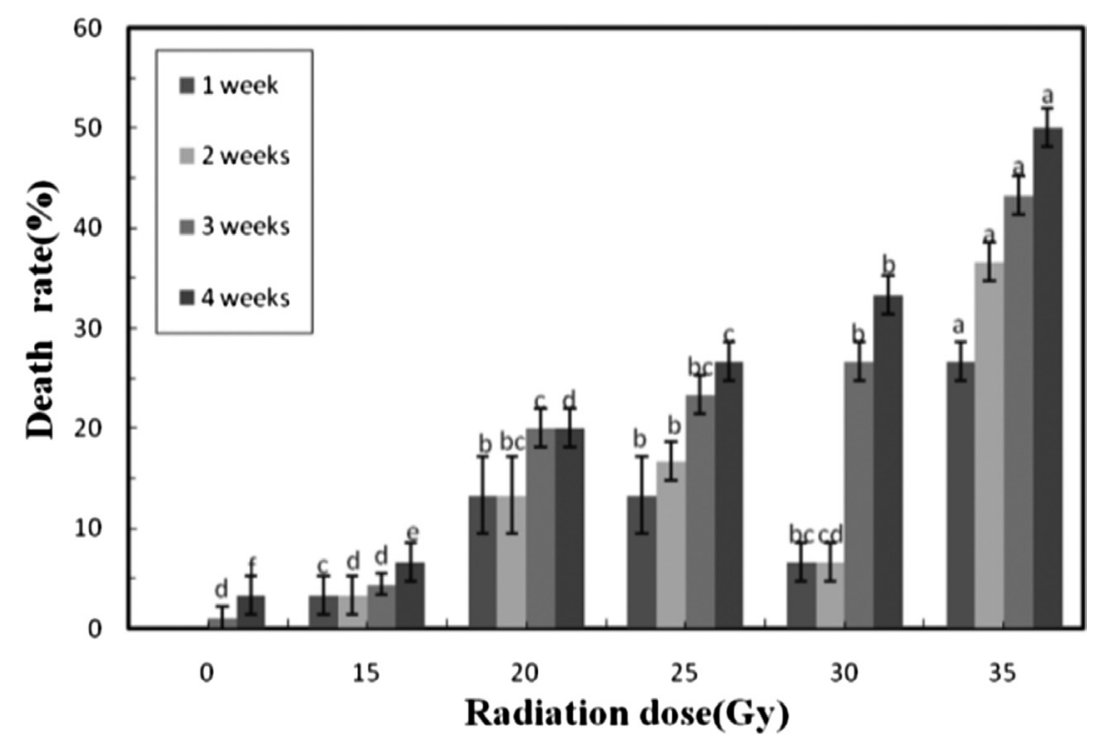

Figure 1. Effect of gamma radiation on the death rate of chrysanthemum 'Donglinruixue' plants at different radiation doses. Mean values were calculated from three experiments. 


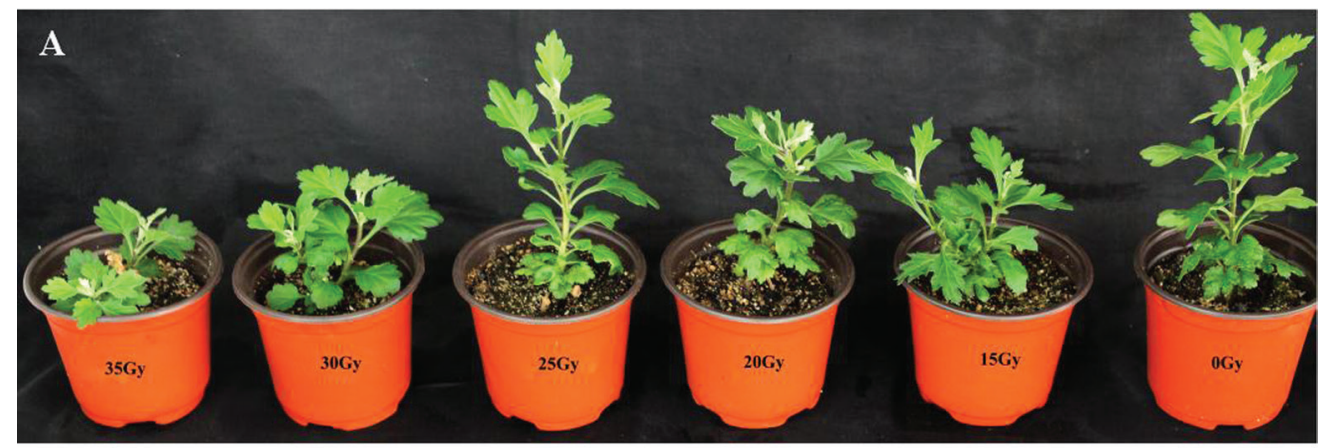

B

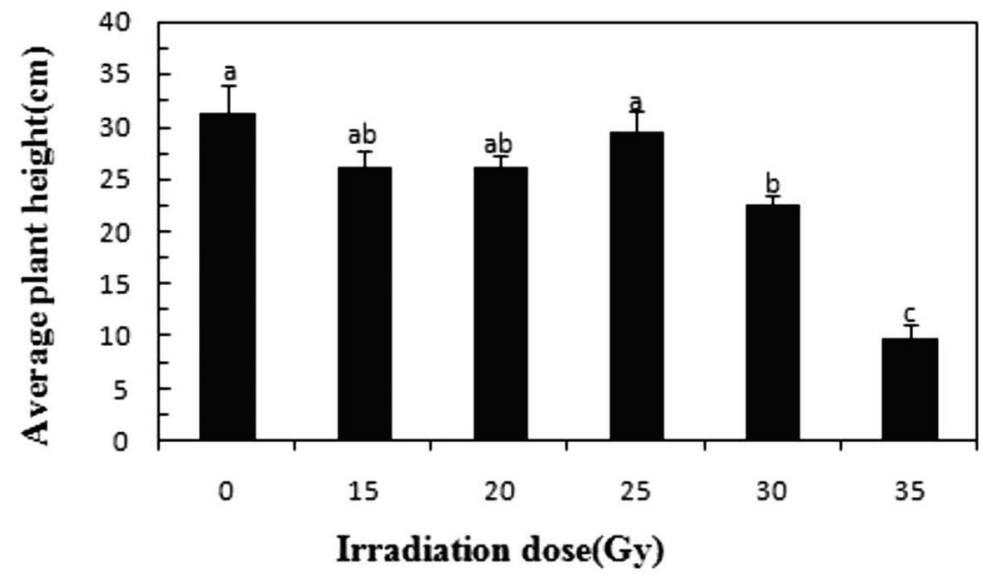

Figure 2. Effect of gamma radiation on average plant height of chrysanthemum 'Donglinruixue' plants at 120 days of plant culture after treatment with different radiation doses. (A) Effect of 0, 15, 20, 25, 30 and 35 Gy radiation. (B) Effect of gamma radiation on average plant height of chrysanthemum 'Donglinruixue' plants at different radiation doses. Mean values and SEM were calculated from three experiments. Within each set of experiments, bars with different letters are significantly different at the 0.05 level.

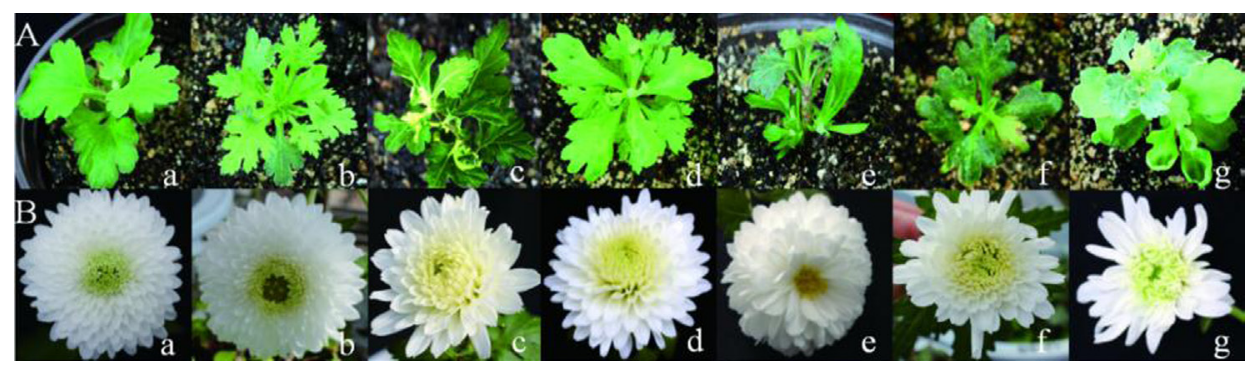

Figure 3. Morphological variations induced by gamma-ray irradiation in chrysanthemum 'Donglinruixue'. (A) Variations in leaves: (a) original leaves on the control plant; (b) increased leaf crack; (c) leaves missing green colour; (d) deformed leaves; (e) lanceolate leaves; (f) leathery leaves and (g) rolled leaves. (B) Variations in flowers: (a) original flowers of the control plant; (b) reduced number of tubular flowers; (c) the top of the petal split; (d) reduced number of petals; (e) petals widened; (f) edge of flower with tubular flowers and (g) twisted lingulate flowers.

(Figure 2). Growth inhibition effect of low doses (15, 20 and 25 Gy) was not significant. After irradiation, a series of morphological variations occurred, such as an increase in leaf cracks (Figure 3A, b), leaves with missing green colour (Figure 3A, c), deformed leaves (Figure 3A, d), lanceolate leaves (Figure 3A, e), leathery leaves (Figure 3A, f) and rolled leaves (Figure 3A, g). Morphological changes in leaves started from 15 Gy treatment and differed in all treatments (Table 2). The rate of morphological variations increased with increasing radiation dose. The peak in variation occurred at $35 \mathrm{~Gy}$. High doses of radiation also caused some physiological damage, such as leathery leaves of mutant plants with yellow wilting (Figure 3A, f). Flower variations included a change in flower type and petal numbers, such as reduced number of tubular flowers (Figure $3 \mathrm{~B}, \mathrm{~b}$ ), the top of the petal split (Figure 3B, c), reduced number of petals (Figure 3B, d), petals widened (Figure 3B, e), the edge of flower with tubular flowers (Figure 3B, f) and twisted lingulate flowers (Figure $3 \mathrm{~B}, \mathrm{~g}$ ). This study also 
Table 2. Effect of gamma radiation on morphological variations of chrysanthemum 'Donglinruixue' plants

\begin{tabular}{|c|c|c|c|c|c|}
\hline \multirow{2}{*}{$\begin{array}{l}\text { Radiation } \\
\text { dose (Gy) }\end{array}$} & \multirow{2}{*}{$\begin{array}{c}\text { Total } \\
\text { number }\end{array}$} & \multicolumn{2}{|c|}{ Variations in leaves after 120 days of culture } & \multicolumn{2}{|c|}{ Variations in flowers after 120 days of culture } \\
\hline & & Number of variants & Rate of variation $(\%)^{*}$ & Number of variants & Rate of variation $(\%)^{*}$ \\
\hline 0 & 87 & 0 & $0.00 \mathrm{f}$ & 0 & $0.00 \mathrm{f}$ \\
\hline 15 & 84 & 6 & $7.14 \mathrm{e}$ & 3 & $3.57 \mathrm{e}$ \\
\hline 20 & 72 & 7 & $9.72 \mathrm{~d}$ & 5 & $6.25 \mathrm{~d}$ \\
\hline 25 & 66 & 13 & $19.96 \mathrm{c}$ & 7 & $11.36 \mathrm{c}$ \\
\hline 30 & 60 & 14 & $23.33 \mathrm{~b}$ & 8 & $12.50 \mathrm{~b}$ \\
\hline 35 & 44 & 12 & $27.27 \mathrm{a}$ & 6 & $13.81 \mathrm{a}$ \\
\hline
\end{tabular}

*These different letters following means are significantly different at $p<0.05$ level.
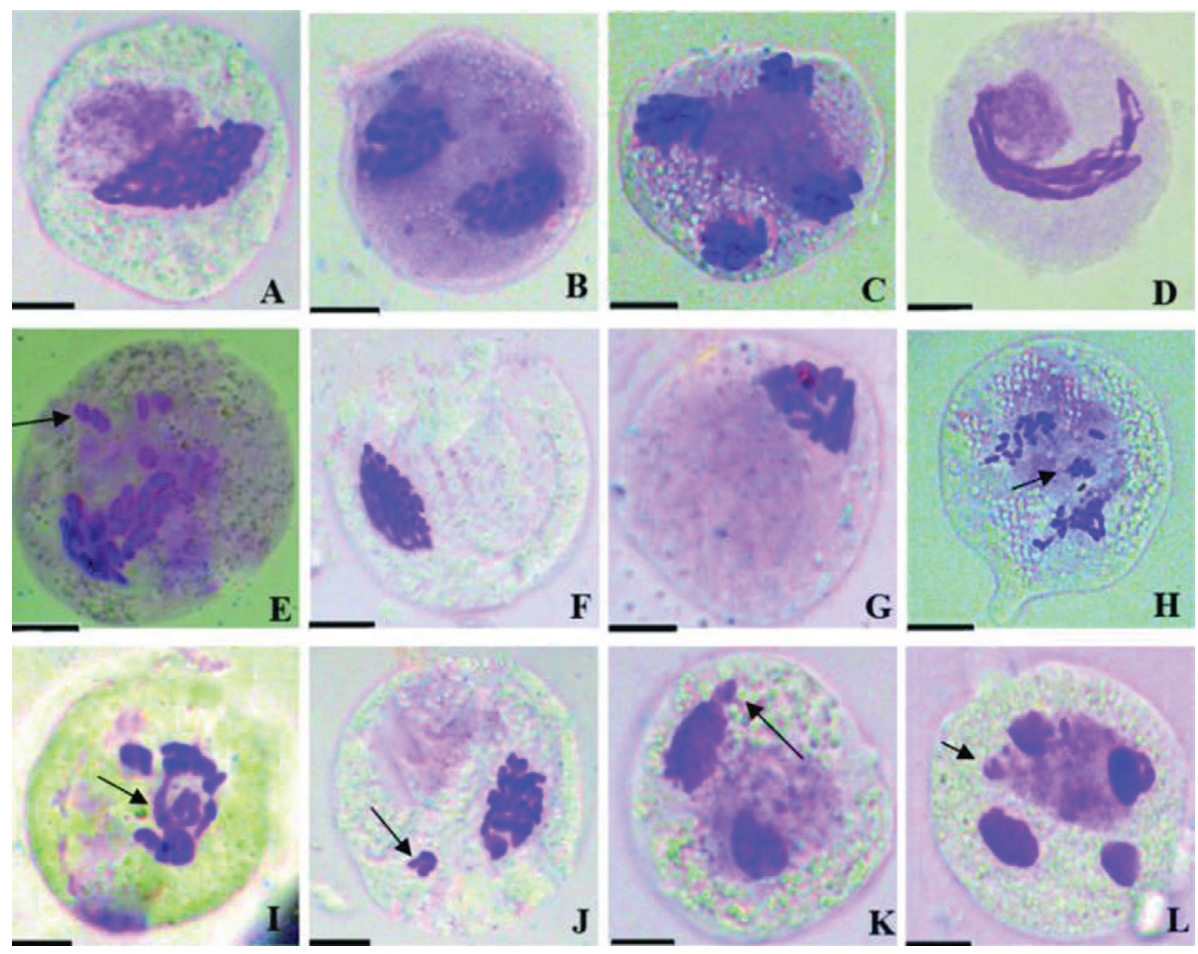

Figure 4. Meiotic behaviour in chrysanthemum 'Donglinruixue' as affected by gamma-ray abnormalities. (A) Normal metaphase I; (B) normal anaphase I; (C) normal anaphase II; (D) stickiness of metaphase I; (E) univalents (indicated by arrow); (F) unipolarity at prophase I; (G) unipolarity at metaphase I; (H) anaphase II with laggard (indicated by arrow); (I) anaphase I showing bridge and fragments (indicated by arrow); (J) micronuclei at prophase I (indicated by arrow); (K) stickiness at metaphase with precocious movement (indicated by arrow) and (L) tetrad with micronuclei (indicated by arrow). Bar $=10 \mu \mathrm{m}$.

observed that radiation groups featured more flower variations but less colour variations.

\section{Effect of radiation on meiotic of 'Donglinruixue'}

Meiosis in 'Donglinruixue' $(2 n=18)$ was normal in the control plants (Figure $4 \mathrm{~A}-\mathrm{C}$ ), but there were several meiotic abnormalities at the treated plants, e.g. stickiness of chromosomes (Figure 4D), univalents (Figure 4E), unipolarity (Figure 4F, 4G), laggards (Figure 4H), bridges (Figure 4I), micronuclei (Figure 4J-L). With the increase of the radiation dose, the percentage of total abnormal cells with chromosome aberrations was significantly increased (Table 3). The number of abnormal cells with stickiness of chromosomes, univalents, laggards, bridges, micronuclei and unipolarity increased with increasing radiation dose. The highest percentage of total abnormal cells appeared at 35 Gy reaching $35.71 \%$, and the incidence of laggards and chromosome bridges was $17.86 \%$. In these abnormal cells, laggards were the highest frequent aberration type.

\section{ISSR analysis}

All 13 primers produced strong, clear and reproducible bands (Table 4 and Figure 5). A total of 72 bands were scorable, and the number of bands for each primer varied between 3 and 9, with a mean of 5.538 bands per primer obtained (Table 4). Percentage of polymorphism ranged from 60 to $100 \%$, with an average polymorphism percentage of $86.84 \%$. Primer ISSR 13 and UBC855 produced a relatively high number of bands (about 
Table 3. The abnormal cells with meiosis aberrations of chrysanthemum 'Donglinruixue' plants due to the irradiation effect

\begin{tabular}{|c|c|c|c|c|c|c|c|c|}
\hline \multirow{2}{*}{$\begin{array}{l}\text { Radiation } \\
\text { dose (Gy) }\end{array}$} & \multirow{2}{*}{$\begin{array}{c}\text { Total PMC } \\
\text { count }\end{array}$} & \multicolumn{6}{|c|}{ Number of cells with aberrations } & \multirow{2}{*}{$\begin{array}{l}\text { Total abnormal } \\
\text { cells }(\%)^{*}\end{array}$} \\
\hline & & Stickiness & Univalent & Laggards & Bridges & Micronuclei & Unipolarity & \\
\hline 0 & 1,000 & 12 & 0 & 4 & 8 & 0 & 0 & $2.40 \mathrm{f}$ \\
\hline 15 & 1,023 & 30 & 12 & 62 & 43 & 25 & 12 & $17.98 \mathrm{e}$ \\
\hline 20 & 1,098 & 34 & 21 & 73 & 76 & 22 & 16 & $21.22 \mathrm{~d}$ \\
\hline 25 & 1,054 & 52 & 28 & 76 & 59 & 26 & 21 & $22.70 \mathrm{c}$ \\
\hline 30 & 1,003 & 78 & 31 & 89 & 79 & 29 & 23 & $32.79 \mathrm{~b}$ \\
\hline 35 & 1,176 & 102 & 38 & 115 & 95 & 39 & 31 & $35.71 \mathrm{a}$ \\
\hline
\end{tabular}

The number of abnormal cells with different chromosome aberrations was recorded.

PMC, Pollen mother cell.

*These different letters following means are significantly different at $p<0.05$ level.

Table 4. List of primers, number of amplified products, polymorphic bands and polymorphism percentage

\begin{tabular}{llccc}
\hline Primer name & Primer sequence (5'-3') & $\begin{array}{c}\text { No. of amplified } \\
\text { bands }\end{array}$ & $\begin{array}{c}\text { No. of polymorphic } \\
\text { bands }\end{array}$ & $\begin{array}{c}\text { Percentage of } \\
\text { polymorphic bands }\end{array}$ \\
\hline UBC873 & GACAGACAGACAGACA & 4 & 3 & 75 \\
UBC836 & AGAGAGAGAGAGAGAGYA & 5 & 3 & 60 \\
UBC857 & ACACACACACACACACCG & 3 & 2 & 66.66 \\
UBC835 & AGAGAG AGAGAGAGAGCC & 6 & 6 & 100 \\
UBC855 & ACACACACACACACACYT & 9 & 8 & 88.89 \\
UBC834 & AGAGAGAGAGAGAGAGYT & 6 & 6 & 100 \\
ISSR13 & TCTCTCTCTCTCTCCC & 9 & 9 & 100 \\
ISSR 20 & ACACACACACACACACGG & 5 & 4 & 80 \\
ISSR 25 & AGAGAGAGAGAGAGAGGA & 4 & 4 & 100 \\
ISSR 26 & AGAGAGAGAGAGAGAGGC & 4 & 4 & 100 \\
ISSR 30 & AGAGAGAGAGAGAGAGCG & 7 & 7 & 100 \\
ISSR 32 & AGAGAGAGAGAGAGAGAT & 4 & 3 & 75 \\
ISSR 34 & ACTCACTCACTCACTC & 6 & 5 & 83.33 \\
Total & & 72 & 64 & $1,128.88$ \\
Mean & & 5.54 & 4.92 & 86.84 \\
\hline
\end{tabular}

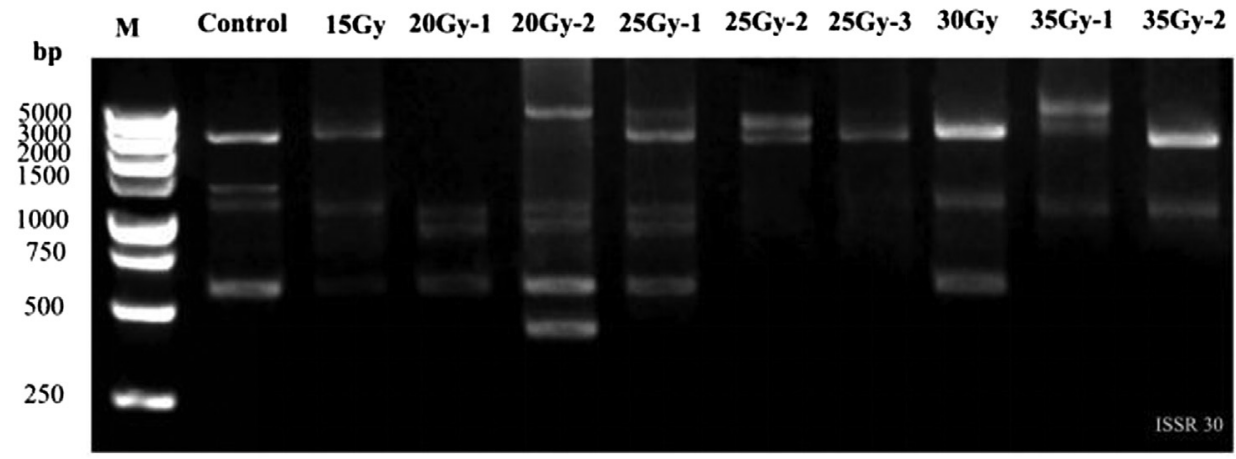

Figure 5. ISSR banding patterns in chrysanthemum 'Donglinruixue' by primer ISSR 30.

nine bands), and the majority of these bands were polymorphic, showing 100 or $88.89 \%$ of polymorphism. Genetic similarity ranged from 0.1765 to 1.000 , with an overall mean of 0.3942 (Table 5). Genetic similarity coefficients of different variants also significantly differed under the same dose treatment. By comparison, genomic DNA of leaf variant material was less mutated, and lower patterns were more varied. Cluster analysis (Figure 6) based on ISSR results showed that mutations were mainly clustered by variation types of apparent traits; clustering results were not directly related to dose, indicating that radiation mutagenicity was random and the same dose cannot cause variation in the same direction. 
Table 5. Proximity matrix based on Jaccard's coefficients

\begin{tabular}{|c|c|c|c|c|c|c|c|c|c|c|}
\hline & Control & 15 Gy & 20 Gy-1 & 20 Gy-2 & 25 Gy-1 & 25 Gy-2 & 25 Gy-3 & $30 \mathrm{~Gy}$ & 35 Gy-1 & 35 Gy-2 \\
\hline Control & 1.000 & & & & & & & & & \\
\hline $15 \mathrm{~Gy}$ & 0.579 & 1.000 & & & & & & & & \\
\hline 20 Gy-1 & 0.292 & 0.293 & 1.000 & & & & & & & \\
\hline 20 Gy-2 & 0.613 & 0.471 & 0.310 & 1.000 & & & & & & \\
\hline 25 Gy-1 & 0.542 & 0.453 & 0.222 & 0.593 & 1.000 & & & & & \\
\hline $25 \mathrm{~Gy}-2$ & 0.278 & 0.233 & 0.306 & 0.230 & 0.300 & 1.000 & & & & \\
\hline 25 Gy-3 & 0.324 & 0.310 & 0.225 & 0.185 & 0.218 & 0.412 & 1.000 & & & \\
\hline $30 \mathrm{~Gy}$ & 0.400 & 0.290 & 0.293 & 0.286 & 0.315 & 0.209 & 0.256 & 1.000 & & \\
\hline 35 Gy-1 & 0.442 & 0.432 & 0.254 & 0.486 & 0.406 & 0.238 & 0.177 & 0.200 & 1.000 & \\
\hline 35 Gy-2 & 0.292 & 0.250 & 0.297 & 0.333 & 0.375 & 0.270 & 0.195 & 0.262 & 0.362 & 1.000 \\
\hline
\end{tabular}

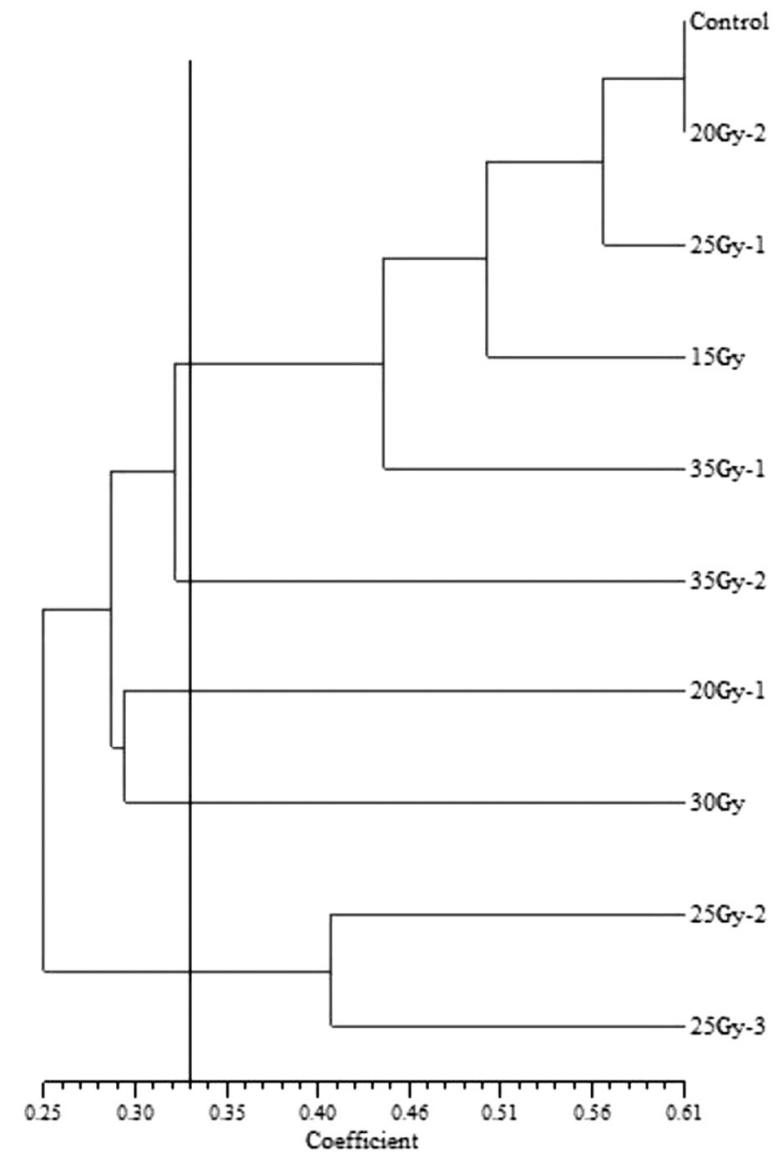

Figure 6. Dendrogram representing morphological variations based on similarity coefficients of ISSR data.

\section{DISCUSSION}

After radiation, the death rate of 'Donglinruixue' generally increased. Semi-lethal state was recorded at 35 Gy. Similar results were obtained in other chrysanthemum genotypes after treatment with gamma rays (Kim et al., 2016). However, the growth of 'Donglinruixue' plants was significantly inhibited with increasing radiation dose. Several studies have reported that radiation reduces plant height. In the growth rate parameter, gamma rays show inhibitory effects (Cheng et al., 2010; Irfan et al., 2017). Similarly, the growth of
'Donglinruixue' plants also showed the same trend at high radiation doses. Some researchers hypothesised that the plasma membrane and cytosolic enzyme systems suffer damage that can lead to inhibition of plant growth and development under high dose of radiation (Fu et al., 2000; Anandhi et al., 2013). We observed that irradiation also caused a series of morphological variations in leaves and flower shapes (Dai and Magnusson, 2012). With increased radiation dose, the types of variations gradually increased. However, most variations occurred in flower shape changes rather than flower colour changes. White flower varieties are more difficult to induce colour variation, which coincides with the results from other researches (Banerji and Datta, 1992).

A series of chromosome aberrations were also observed after gamma-ray radiation treatment. In metaphase I, a high level of chromosomal stickiness took place. The percentage of total abnormal cells with chromosomal stickiness was significantly increased with increasing radiation dose. Similar results were obtained after treatment with gamma rays (Kolar et al., 2013). The characteristic of chromosome stickiness is the clustering of any phase of the cell cycle. The severe case of stickiness could lead to the formation of numerous pycnotic nuclei. In the current study, this phenomenon was also the cause of a large number of micronuclei formation. Chromosome stickiness may be caused by genetic or environmental factors (Arabbeigi et al., 2010). Some researchers thought that the chromatin fibres fail to condense properly at synizesis stage, so that they may be captured and tangled with fibres of other chromosomes, getting physically connected. Such abnormal chromatid connections finally cause many chromosomes to adhere to one another, and hence the stickiness results (Andréa et al., 2009). The univalents were observed in both the control and the treated samples. With the increase in radiation dose, the percentage of total abnormal cells with univalents showed an increasing trend. The reason for the formation of univalents is that chromosomes altogether failed to pair at zygotene, or its two-component chromosomes are separated at diplotene because of the absence of chiasma formation. Besides, it is also due to the precocious anaphasic separation of 
bivalent (Sarbhoy, 1977). In this article, the appearance of univalents may be due to the translocation and reversal of chromosomes caused by radiation treatment, so that homologous chromosomes are not juxtaposed and cannot be paired. In anaphase I, mutagenic treatment induced several laggards. Also, the occurrence of cells with laggard chromosome represented the increasing trend with the increasing dose. The occurrence of cells with laggard chromosome may be due to abnormal spindle formation, and as a result spindle fibres failed to carry the respective chromosomes to the polar region (Tarar and Dnyansagar, 1980). The occurrence of fragments may be attributed to the failure of broken chromosome to recombine it (Kaur and Grover, 1985). Another interesting abnormality noticed in the present study is the formation of bridges at anaphase. The most notable characteristic of the bridges is due to the general stickiness of the chromosomes, rather than lagging acentric fragments. The formation of bridges might be due to chiasmata failure to terminalise at diplotene, so the chromosomes get stretched between the poles (Saylor and Smith, 1966). In addition, other abnormalities such as unipolarity at metaphase I was also encountered at the treated sets. The highest percentage of micronuclei recorded in the treatment sets was $2.64 \%$, which is more in contrast to the control. The abnormalities that were observed in earlier phases of the meiotic cycle led to the appearance of micronuclei. In the present study, the abnormality may be due to the presence of fragments or laggards and may lead to the variation in the number and size of pollen grains developed from the microspore mother cells. Micronucleus frequency can be used as a measure of chromosomal damage caused by radiation. In the current study, the proportion of micronuclei was positively correlated with radiation, indicating that high doses of radiation caused plant damage.

To reduce the reproductive cycle and breed expected new varieties fleetly, it is important to use molecular markers to test mutants at an early stage. ISSR analysis showing genetic variation among untreated and radiated plants will be useful in distinguishing variants with differences in morphological characteristics (Žiarovská et al., 2013). In the current study, DNA amplifications were successfully performed for all 13 ISSR primers. A total of 72 bands were scorable, of which 64 (88.89\%) were found to be polymorphic. The number of bands produced by primers ranged from three to nine, with an average of 5.54 bands per primer obtained. These results indicate that the application of gamma irradiation may be an effective method of mutation induction, as proven previously (Pestanana et al., 2011; Lee and Han, 2014). Genetic similarity among treatments with different doses ranged from 0.177 to 1.000 , with an average genetic similarity of 0.394 . It was revealed that DNA changes had occurred in these materials and the dendrogram, showing the formation of five main groups of mutants, and that indicated the effects of different irradiation dosages on seedlings are far from each other. This result was in accordance with the studies on Sophora davidii (Wang et al., 2017), lily (Xi et al., 2012) and banana (Khan, 2011). Also, there is a genetic gap between dwarfing plants and other types of variation, and it can be concluded that the dwarfing plants have a genetic level change that is of great significance for obtaining dwarfing varieties of ground-grown chrysanthemum and the mutants were successfully identified through ISSR analysis.

\section{CONCLUSION}

In conclusion, the current study demonstrated that high doses (35 Gy) of radiation exhibit strong mutagenic potency that could be an important parameter for the 'Donglinruixue' cultivar improvement. Semi-lethal state was stimulated at $35 \mathrm{~Gy}$. The chromosome aberrations, morphological characteristics and genomic DNA featured a large degree of variations. The current study also obtained the desired genetic variations.

\section{FUNDING}

This work was funded by the Fundamental Research Funds for the Central Universities (2572019BK03).

\section{AUTHOR CONTRIBUTIONS}

L.W. and J.W. developed the concept and assumptions. J.W. and F.L. designed experiments. J.W., F.L. and P.G. performed the experiments and analysed the data. J.W. and F.L. wrote the paper.

\section{CONFLICT OF INTEREST}

The authors declare no conflict of interest.

\section{REFERENCES}

Afrasiab, H., and Igbal J. (2011). Genetic analysis of somaclonal variants and induced mutants of potato (Solanum tuberosum L.) cv. Diamant using RAPD markers. Pakistan Journal of Botany, 44, 215-220.

Ahloowalia, B. S., And Maluszynski, M. (2001). Induced mutations - A new paradigm in plant breeding. Euphytica, 118, 167-173.

Anandhi, S., Rajamani, K., Jawaharlal, M., Maheshwaran, M., and Gnanam, R. (2013). Colchicine content in induced mutants of Glory Lily (Gloriosa superba L.). International Journal of Agriculture Innovations and Research, 1(6), 214-216.

Andréa, B. M. B., Maria, S. P., Cacilda, B. D. V., And Maria, I. D. O. P. (2009). A severe case of chromosome stickiness in pollen mother cells of Brachiaria brizantha (Hochst.) Stapf (Gramineae). Cytologia, 66, 287-291. 
Arabbeigi, M., Arzani, A., And Saeidi, G. (2010). Meiotic behavior of wild, synthetic and cultivated wheats. Cytologia, 75, 169-175.

Banelji, B. K., And Datta, S. K. (1992). Gamma ray induced flower shape mutation in Chrysanthemum cv. 'Jaya'. Journal of Nuclear Agriculture and Biology, 21, 73-79.

Banelji, B. K., And DattA, S. K. (2006). Induction and analysis of induced somatic mutation in Chrysanthemum cultivar 'Surekha'. Bharatiya Vaigyanik evam Audyogik Anusandhan Patrika, 14, 34-38.

Chen, J. Y., Wang, S., Wang, X. C., and Wang, P. W. (1995). Thirty years' studies on breeding groundcover chrysanthemum new cultivars. Acta Horticulturae, 404, 124-135.

Cheng, L., Yang, H., Lin, B., Wang, Y., Li, W., Wang, D., AND ZHANG, F. (2010). Effect of gamma-ray radiation on physiological, morphological characters and chromosome aberrations of minitubers in Solanum tuberosum L. International Journal of Radiation Biology, 86, 791-799.

DAI, W., And Magnusson, V. (2012). Morphological variations in Buddleia induced by gamma ray irradiation. Hortscience, 47, 81-83.

Fu, X., Zhang, Z., He, P., Ou, X., and He, Q. (2000). The effect of ${ }^{60} \mathrm{Co} \gamma$-ray irradiation on the growth and regeneration of Cymbidium sinense rhizome. Acta Agriculturae Nucleatae Sinica, 14, 333-336.

Hwang, S. G., Dong, S. K., Kim, J. B., Hwang, J. E., PARK, H. M., Jin, H. K., AND JANG, C. S. (2016). Transcriptome analysis of reproductive-stage Arabidopsis plants exposed gamma-ray irradiation at various doses. International Journal of Radiation Biology, 92,1-15.

Irfan, A. B., Umar, J. P., Imtiyaz, A. S., and Zia, U. H. (2017). Physical and chemical mutagenesis in Linum usitatissimum L. to induce variability in seed germination, survival and growth rate traits. Current Botany, 7, 28-32.

Kang, E. J., Lee, Y. M., SAng, Y. S., Ha, B. K., SAng, H. K., Dong, S. K., KIM, J. B., AND KanG, S. Y. (2013). Analysis of the genetic relationship of gammairradiated in vitro mutants derived from standardtype chrysanthemum cv. Migok. Horticulture, Environment, and Biotechnology, 54, 76-81.

Kaur, P., And Grover, I. S. (1985). Cytological effects of some organophosphorus pesticides. Cytologia, 50, 199-211.

Khan, I. (2011). In vitro mutagenesis in banana and variant screening through ISSR. Pakistan Journal of Botany, 43, 2427-2431.

Kim, Y. S., SAnG, Y. S., Jo, J. D., Lee, H. J., And SAnG, H. K. (2016). Effects of gamma ray dose rate and sucrose treatment on mutation induction in chrysanthemum. European Journal of Horticultural Science, 81, 212-218.
Kolar, F. R., Pai, S. R., And Dixit, G. B. (2013). EMS, sodium azide and gamma rays induced meiotic anomalies in Delphinium malabaricum (Huth) Munz. Israel Journal of Plant Sciences, 61, 64-72.

Kovacs, C. S. E., And Keresztes, A. (2002). Effect of gamma and UV-B/C radiation on plant cells. Micron, 33, 199.

Lamseejan, S., Jompuk, P., Wongpiyasatid, A., Deeseepan, S., and Kwanthammachart, P. (2000). Gamma-rays induced morphological changes in chrysanthemum. (Chrysanthemum morifolium). Kasetsart Journal (Natural Science), 34, 417-422.

LeE, J. H., And Han, T. H. (2014). Selection of mutants obtained by gamma ray irradiation and analysis of genetic variation using RAPD markers in Acorus calamus L. Horticulture, Environment, and Biotechnology, 55, 207-212.

Mahto, R., And DAs, M. (2014). Effect of gamma irradiation on the physico-mechanical and chemical properties of potato (Solanum tuberosum L.), cv. 'Kufri Sindhuri', in non-refrigerated storage conditions. Postharvest Biology and Technology, 92, $37-45$.

Majeed, A., Khan, A. U. R., Ahmad, H., AND Munammad, Z. (2009). Gamma irradiation effects on some growth parameters of Lepidium sativum L. American-Eurasian Journal of Sustainable Agriculture, 122, 502-508.

Mariano, L. C., Zchonski, F. L., DA Silva, C. M., AND DA-SilvA, P. R. (2019). Genetic variability in a Brazilian apple germplasm collection with low chilling requirements. PeerJ, 6, e6265.

Matsumura, A., Nomizu, T., Furutani, N., Hayashi, K., Minamiyama, Y., and Hase, Y. (2010). Ray florets color and shape mutants induced by ${ }^{12} \mathrm{C}^{5+}$ ion beam irradiation in chrysanthemum. Scientia Horticulturae, 123, 558-561.

Mejri, S., Mabrouk, Y., Voisin, M., Delavault, P., Simier, P., Saidi, M., And Belhadj, O. (2012). Variation in quantitative characters of faba bean after seed irradiation and associated molecular changes. African Journal of Biotechnology, 11, 8383-8390.

Mudibu, J., Nkongolo, K. K. C., Mehes-Smit, M., And KalOnjI-MB, A. (2002). Genetic analysis of a soybean genetic pool using ISSR marker: Effect of gamma radiation on genetic variability. International Journal of Plant Breeding and Genetics, 5, 235-245.

Pestanana, R. K. N., Amorim, E. P., Ferreira, C. F., Oliveira, L. S., Ledo, C. A. D. S., and Silva, S. D. O. E. (2011). Agronomic and molecular characterization of gamma ray induced banana (Musa sp.) mutants using a multivariate statistical algorithm. Euphytica, 178, 151-158.

Rustikawati, R., Suprijono, E., Romeida, A., And Herison, C. (2012). Identification of M4 gamma 
irradiated maize mutant based on RAPD markers. Agrivita, 34, 161-165.

Sarbhoy, R. K. (1977). Cytogenetical studies in the genus Phaseolus Linn: III. Evolution in the genus Phaseolus. Cytologia, 42, 401-413.

Saylor, L. C., And Smith, B. W. (1966). Meiotic irregularity in species and interspecific hybrids of Pinus. American Journal of Botany, 53, 453-468.

Sung, S. Y., Kim, S. H., Velusamy, V., Lee, Y. M., HA, B. K., KIM, J. B., KANG, S. Y., Hong, G. K., AND Dong, S. K. (2013). Comparative gene expression analysis in a highly anthocyanin pigmented mutant of colorless chrysanthemum. Molecular Biology Reports, 40, 5177-5189.

Taheri, S., Abdullah, T. L., Abdullah, N. A. P., And Ahmad, Z. (2013). Use of intersimple sequence repeat assay for detection of DNA polymorphism induced by gamma rays in Curcuma alismatifolia. Hortscience, 48, 1346-1351.

TARAR, J. L., AND DNyAnsagar, V. R. (1980). Comparison of ethyl methanesulfonate and radiation induced meiotic abnormalities in Turnera ulmifolia Linn. var. angustifolia Willd. Cytologia, 45, 221-231.

WALther, F. (1969). Effectiveness of mutagenic treatments with ionizing radiation in barley. In Induced Mutations in Plants. Proceedings Series - International Atomic Energy Agency, Vienna, Austria, IAEA.
Wang, P., Zhang, Y., ZhaO, L., Mo, B., and Luo, T. (2017). Effect of gamma rays on Sophora davidii and detection of DNA polymorphism through ISSR marker. BioMed Research International, 2017, 1-6.

WANi, A. A., AND ANIS, M. (2008). Gamma ray- and EMS-induced bold-seeded high-yielding mutants in chickpea (Cicer arietinum L.). Turkish Journal of Biology, 32, 161-166.

Xi, M., Sun, L., Qiu, S., Liu, J., Xu, J., And Shi, J. (2012). In vitro mutagenesis and identification of mutants via ISSR in lily (Lilium longiflorum). Plant Cell Reports, 31, 1043-1051.

Yamaguchi, H., Shimizu, A., Degi, K., And Morishita, T. (2008). Effects of dose and dose rate of gamma ray irradiation on mutation induction and nuclear DNA content in chrysanthemum. Breeding Science, 58, 331-335.

ŽiarovskÁ, J., RažnÁ, K., AND Labajová, M. (2013). Using of inter microsatellite polymorphism to evaluate gamma-irradiated Amaranth mutants. Emirates Journal of Food and Agriculture, 25, 673-681.

Zietkiewicz, E., Rafalski, A., And Labuda, D. (1994). Genome fingerprinting by simple sequence repeat (SSR)-anchored polymerase chain reaction amplification. Genomics, 20, 176-183.

Received: December 13, 2019; accepted: March 31, 2020 